\title{
Customer Satisfaction and the moderating effect of Demographics in Public Sector Banks
}

\author{
${ }^{1}$ Mukta Dewan, ${ }^{2}$ Dr Sadhana Mahajan \\ ${ }^{1}$ Research Scholar, Faculty of Commerce and Management Studies, Himachal Pradesh University Business \\ School, Shimla - 171005, India. \\ 2Professor, Faculty of Commerce and Management Studies, Himachal Pradesh University Business School, \\ Shimla - 171005, India.
}

\begin{abstract}
The purpose of conducting this research was to explore the customer satisfaction in the public sector banks. The moderating effect of various demographic and situational factors was taken into consideration. This research was mainly based on primary data which had been collected through a well-structured questionnaire The questionnaire had been distributed to 300 respondents. This paper makes a useful contribution as there are very low number of studies that have been conducted in India on such dimensions. This research showed that the customer satisfaction varies from person to person and, bank managers need to conduct more researches in order to evaluate it more strongly.
\end{abstract}

Keywords: Customer Satisfaction, demographics, Public Banks.

\section{Introduction}

Nationalised banks or public banks dominate the banking System in India. The nationalisation of banks in India took place in 1969 by Mrs. Indira Gandhi the then prime minister. The major objective behind nationalisation was to spread banking infrastructure in rural areas and make available cheap finance to Indian farmers. Before 1969, State Bank of India (SBI) was the only public sector bank in India. Despite the entry of many new domestic private and foreign banks since liberalization, public sector banks continue to dominate the commercial banking industry.

Banking is a high involvement industry. Banks recognize the fact that delivery of quality service to customers is essential for success and survival in today's global and competitive banking environment (Wang, Han, \& Wen, 2003). Researchers have found that customer satisfaction has a measurable impact on purchase intentions (Carter, 2010), on customer retention (Voss \& Voss, 2008) and on a firm's financial performance (Chalmeta, 2006).Customer satisfaction is the key to long term success of any organization (Peppers \& Rogers, 2005). Keeping the importance of customer satisfaction in mind, banks need to maintain stable and close relationships with their customers. Customer satisfaction levels need to be judged. The application of the knowledge of customer satisfaction is imperative to establishing and maintaining a long-term relationship with customers and long-term competitiveness (Kumar \&Reinartz, 2006).

Customers' wants, needs, and expectations change quickly. Therefore, what would have delighted and surprised them a short while back might not satisfy them at present (Richards \& Jones, 2008). Banks may not be able to provide superior services to the customers unless customer expectations are known (Leverin\&Liljander, 2006). Customer expectations can be known through the knowledge of satisfaction levels of customers (Jham\& Khan, 2009). Identifying the customer satisfaction levels should be a central concern for retail bank managers as well as service management academicians and practitioners. Satisfied customers help to build and maintain customer relationship that is the key success in current banking scenario. Satisfied customers typically can help to get higher market share and better returns. Many of the previous studies have been undertaken in western world with little inputs from Indian context. India is a culturally and economically diverse society with varying demographic characteristics as compared to western world. Hence scope of present research presents Indian economic context

\subsection{Customer Satisfaction}

\section{Literature Review}

Customer satisfaction is the degree of overall pleasure or contentment felt by the customer, resulting from the ability of the service to fulfill the customer's desires, expectations and needs in relation to the service (Kotler, 2004). It is the consumers' overall evaluation based on their overall experience and it can be viewed in two ways -transaction-specific outcome or cumulative evaluation (Wang et aI., 2004). Anderson and Sullivan (1993) suggested that 'Satisfaction can be broadly characterised as a post-purchase evaluation of product quality given pre purchase expectations'. 
According to Oliver (1996) 'Satisfaction is the consumer's fulfillment response. It is a judgment that a product or service feature, or the product of service itself, provided (or is providing) a pleasurable level of consumption-related fulfillment including levels of under-or over-fulfillment'. Accordingly customers purchase goods and services with pre-purchase expectations about anticipated performance. When outcome matches expectations, confirmation occurs. Disconfirmation occurs when there are differences between expectations and outcomes. Negative disconfirmation occurs when product/service performance is less than expected. Positive disconfirmation occurs when product/service performance is better than consumer expectations, and dissatisfaction is caused by negative disconfirmation of consumer expectations.

Vavra's (1997) stated that customer satisfaction characterises satisfaction as the end-state resulting from the experience of consumption. This end state may be a cognitive state of reward, an emotional response to an experience or a comparison of rewards and costs to the anticipated consequences. Kolter and Armstrong (1999) defended the customer satisfaction as the customer's perception that compared their pre-purchase expectations with post purchase perception. Customer satisfaction was the customers' evaluation of services after purchase as opposed to their expectation (Oliver, 1997; Zeithaml and Bitner, 2000). Baker and Crompton (2000) defended satisfaction as a personal experience and mentality related the nitration between personal expectation and actual receive. Customer satisfaction was the overall evaluation to services. It was the reflection customers make to their previous purchase.

Thus, when a customer is contented with either the product or services it is termed Satisfaction (Kotler \& Keller, 2009, p. 789). Satisfaction can also be a person's feelings of pleasure or disappointment that results from comparing a product's perceived performance or outcome with their expectations (Levy 2009).

It has however been identified that human needs, quality of services and products, the user friendly nature of product and services, and comfort assurance (Homburg et al.,(2001)) are some of the important determinants of customer satisfaction. Even though different customers will require different levels and combinations of these variables, they generally are important factors that affect customer satisfaction. Matzler et al., (2002), went a step forward to classify factors that affect customers' satisfaction into three factor structures;

- Basic factors: these are the minimum requirements that are required to prevent the customer from being dissatisfied. They do not necessarily cause satisfaction but lead to dissatisfaction if absent. These are those factors that lead to the fulfillment of the basic requirement for which the product is produced. These constitute the basic attributes of the product or service. They thus have a low impact on satisfaction even though they are a prerequisite for satisfaction. In a nutshell they are competence and accessibility

- Performance factors: these are the factors that lead to satisfaction if fulfilled and can lead to dissatisfaction if not fulfilled. These include reliability and friendliness.

- Excitement factors: these are factors that increase customers' satisfaction if fulfilled but does not cause dissatisfaction if not fulfilled. In other words, positive performance on these attributes has a greater impact on overall satisfaction than negative performance. Excitement factors surprise the customer and generate "delight."

Zeithaml, Bitner \& Gremler( 2009) identified the combination of following elements for measuring satisfaction; perception of service quality, price, product quality, personal factors and situational; this is illustrated in Fig-1below.

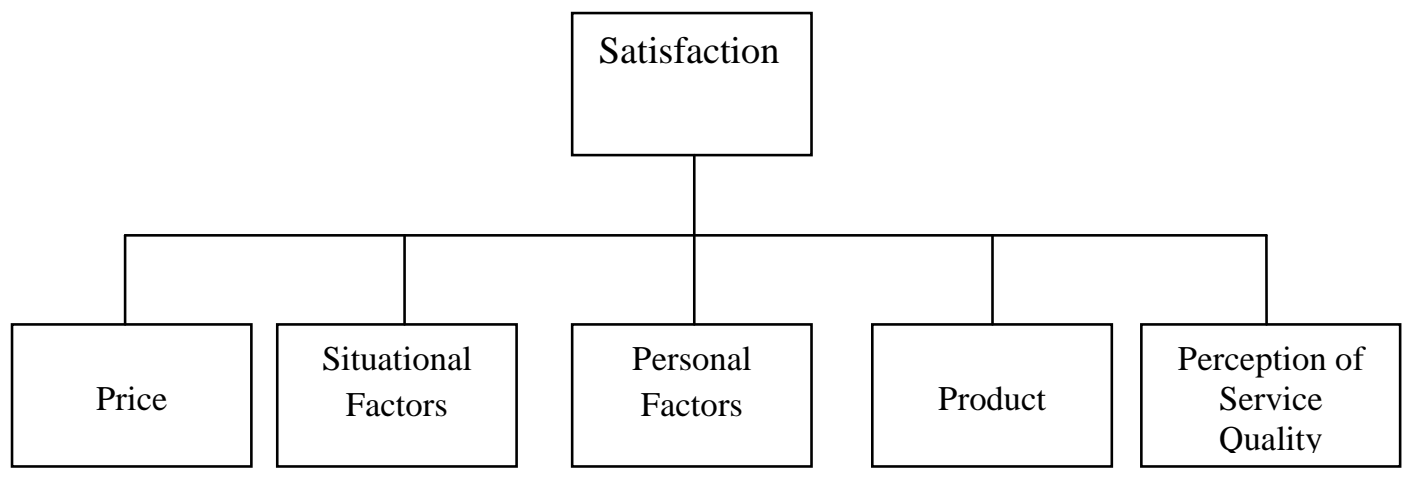

Figure-1 Satisfaction components (Source: Adapted from Zeithaml, Bitner and Gremler (2009))

\subsection{Moderating effect of Demographics and Situational factors on Customer Satisfaction}

Demographic information allows researchers to obtain characteristics of their sample therefore making the classification of the data more meaningful (Elanain, 2003).

Other studies found that there are differences in shopping behaviour when it involves gender (Foucault \&Scheufele, 2002). Gender is important in the Arab world, for instance females prefer to go to banks that have 
dedicated female branches. Other research supports the need to have banks that are in line with the social and religion values of the customer (Jabnoun \&Khalifa, 2005). Women-only branches are preferred because they are in line with social and religious values for some customers.

Bryant et al. (1996) conducted a study on 400 companies using the American Customer Satisfaction Index (ACSI) and demonstrated that there is significant relationship and consistent differences in the levels of satisfaction among demographic groups

Palvia and Palvia (1999) found out that age is a significant determinant of satisfaction with information technology industry. Oyewole (2001) in his research on customer satisfaction with airline services reported also that gender, occupation, education, and marital status have significant influence on customer satisfaction, while age and household income had no significant influence.

According to Ogden \& Ogden (2005) the most important demographic information is 'marital status' because it shows if customers are buying for themselves, for a spouse, or a family with children. Education level is an important demographic information because as customers `become more educated they demand different products and different levels of service (Kent \& Omar, 2003).

Kotler\& Armstrong (2010) suggest there has been an increase in educated people in the United States and this leads to an increase in the demand for quality products.

A study by Kim \& Jin (2002), looked at the number of visits the customers made to their preferred discount shop in Korea and USA, but there were no further analyses made to find any correlations between the number of visits and the different dimensions.Income has a relationship with purchasing decisions, thus high income customers gather information prior to buying a product and this may have an influence on satisfaction (Homburg \&Giering, 2001).

From this literature review, it is suggested that consumers differ in behaviors and attitudes and one of the factors responsible for this difference is demographics. It is therefore necessary to investigate the moderating effect of demographic factors (age, gender, type of employment, marital status and income) and situational factors (frequency of visits, years of relationship) on customer satisfaction.

\section{Model and Hypotheses}

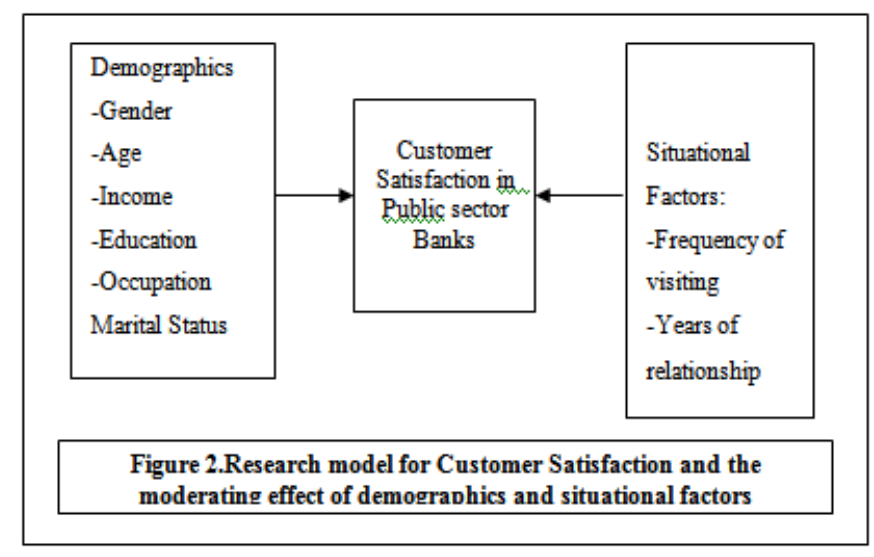

\section{Hypotheses}

The study considered the moderating effect of variables which included 6 demographic factors: (i) Gender (ii) Age (iii) Income (iv)Education (v) Occupation (vi) Marital Status and two situational factors (i) Frequency of visiting the bank (ii) Years of relationship with the bank. The review of literature indicated that the customers differ in their satisfaction levels. The difference may be due to some demographic factors and situational factors. The hypotheses were formulated as under:

H1: There would be a significant difference in the Customer satisfaction of SBI customers on the basis of gender.

H2: There would be a significant difference in the Customer satisfaction of the SBI customers on the basis of age.

H3: There would be a significant difference in the Customer satisfaction of the SBI customers on the basis of income.

H4: There would be a significant difference in the Customer satisfaction of the SBI customers on the basis of educational backgrounds. 
H5: There would be a significant difference in the Customer satisfaction of the SBI customers on the basis of Occupation.

H6: There would be a significant difference in the Customer satisfaction of the SBI customers on the basis of marital status.

H7: There would be a significant difference in the Customer satisfaction of the SBI customers on the basis of frequency of visiting the Bank.

H8: There would be a significant difference in the Customer satisfaction of the SBI customers on the basis of years of relationship with the Bank.

\section{Methodology}

The research has been conducted in the tricity region of Chandigarh, Panchkula and Mohali. The three branches of State Bank of India with 300 customers have been selected for the present study through convenient sampling technique and data and information pertain to the year 2012-2013. Customer Satisfaction was operationalised by 12 items which measured overall general satisfaction. It included items related to concern for customers needs, fair charges, services as value for money, procedures of the bank and overall delight in choosing the bank. All items were measured on the five-point Likert scale ranging from 1 (strongly disagree) to 5 (strongly agree). Thus the score ranged from (12-65). The validity of the questions for measuring customer satisfaction was checked through reliability coefficient Cronbach's alpha (the value was .887).In order to accomplish the objectives, Ttest and Anova have been applied.

\section{Results and Discussions}

\subsection{The Demographic and Situational characteristics of customers}

The demographic characteristics of customers of the public sector bank were analysed and the results are presented in Table-1. Results of description showed that the SBI sample consists of greater percentage of males customers $(62.9 \%)$ than female customers. Majority of the respondents/customers $(76.5 \%)$ were in the age group 25-40 years .Most of the customers were Post graduates (73.5\%). Majority of the respondents belonged to the salaried class $(61.4 \%)$. Most of the customers had an annual income of up to 5 lacs $(62.9 \%)$. The respondents of the SBI had a greater percentage of married customers $(64.4 \%)$ than the unmarried customers. The frequency of visiting the bank was the maximum for monthly visitors $(62.1 \%)$. When the years of relationship were considered, maximum number of respondents belonged to greater than 5 yrs group (59.1\%).

Table-1 Demographic and Situational Characteristics of the Customers

\begin{tabular}{|c|c|c|}
\hline Particulars & Frequency & Percent \\
\hline \multicolumn{3}{|l|}{ Gender } \\
\hline Male & 166 & 62.9 \\
\hline Female & 98 & 37.1 \\
\hline \multicolumn{3}{|l|}{ Age } \\
\hline$<25 \mathrm{yrs}$ & 16 & 6.1 \\
\hline $25-40$ yrs & 202 & 76.5 \\
\hline$>40 \mathrm{yrs}$ & 46 & 17.4 \\
\hline \multicolumn{3}{|l|}{ Annual Income } \\
\hline Upto 5 lacs & 166 & 62.9 \\
\hline 5 lac-15lac & 84 & 31.8 \\
\hline$>15$ lac & 14 & 5.3 \\
\hline \multicolumn{3}{|l|}{ Education } \\
\hline Graduate and below & 70 & 26.5 \\
\hline Post Grad and above & 194 & 73.5 \\
\hline \multicolumn{3}{|l|}{ Occupation } \\
\hline Salaried & 162 & 61.4 \\
\hline Business & 22 & 8.3 \\
\hline Retired & 12 & 4.5 \\
\hline Housewife & 20 & 7.6 \\
\hline Student & 48 & 18.2 \\
\hline \multicolumn{3}{|l|}{ Marital Status } \\
\hline Married & 170 & 64.4 \\
\hline Unmarried & 94 & 35.6 \\
\hline \multicolumn{3}{|c|}{ Frequency of visiting the bank } \\
\hline Once a week & 24 & 9.1 \\
\hline 2-5 times/week & 32 & 12.1 \\
\hline Fortnightly & 44 & 16.7 \\
\hline Monthly & 164 & 62.1 \\
\hline \multicolumn{3}{|l|}{ Years of Relationship } \\
\hline$<1$ year & 14 & 5.3 \\
\hline $1-2$ years & 40 & 15.2 \\
\hline $2-5$ years & 54 & 20.5 \\
\hline$>5$ years & 156 & 59.1 \\
\hline
\end{tabular}




\subsection{Difference in the customer satisfaction of SBI Customers on the basis of Gender}

Independent $\mathrm{t}$-test revealed (Table-2) that there was a significant difference in the Customer satisfaction of SBI customers on the basis of Gender $(\mathrm{t}=2.227)$. The calculated $\mathrm{t}$-value is greater than the table value. Thus Hypothesis H.1 for significant difference based on gender was accepted.

Table -2 T-test for the difference in the customer satisfaction of SBI Customers on the basis of gender and marital status

\begin{tabular}{|c|c|c|c|c|c|}
\hline & Group Sta & & & & \\
\hline & Gender & $\mathbf{N}$ & Mean & Std. & t-value \\
\hline \multirow{5}{*}{ Customer Satisfaction } & Male & 166 & 39.40 & 8.305 & \multirow{2}{*}{$2.227 *$} \\
\hline & Female & 98 & 41.59 & 6.649 & \\
\hline & Marital Status & $\mathbf{N}$ & Mean & Std. & t-value \\
\hline & Married & 170 & 39.53 & 8.019 & \multirow{2}{*}{$1.97 *$} \\
\hline & Unmarried & 94 & 41.45 & 7.240 & \\
\hline
\end{tabular}

$* 0.05$ level of significance

\subsection{Difference in the customer satisfaction of SBI Customers on the basis of Marital Status}

Independent t-test revealed (Table 2) that there was a significant difference in the Customer satisfaction of SBI customers on the basis of Marital status ( $\mathrm{t}=1.97)$. The calculated $\mathrm{t}$-value is greater than the table value. Thus Hypothesis H6 for significant difference based on marital status was accepted.

5.4 Difference in the customer satisfaction of SBI Customers on the basis of Age, Income, Education, Occupation, Frequency of visiting and Years of Relationship with the bank

ANOVA test indicated (Table-3) that there was a significant difference in the Customer Satisfaction of SBI customers on the basis of age, occupation and frequency of visiting the bank (F calculated is greater than the table value at 5\% level of significance). Hence Hypotheses $\mathrm{H} 2, \mathrm{H} 5, \mathrm{H} 7$ based age, occupation and frequency of visiting the bank respectively are accepted. The remaining hypotheses $\mathrm{H} 3, \mathrm{H} 4, \mathrm{H} 8$ for significant difference based on income, education, and years of relationship with the bank were not accepted for customer satisfaction.

ANOVA test for the difference in the customer satisfaction of SBI Customers on the basis of Age, Income, Education, Occupation, Frequency of visiting and Years of Relationship with the bank

\begin{tabular}{|c|c|c|c|c|c|}
\hline \multicolumn{6}{|c|}{ ANOVA } \\
\hline & Customer Satisfaction & Sum of Squares & df & Mean Square & $\mathbf{F}$ \\
\hline \multirow[t]{3}{*}{ Age } & Between Groups & 1405.558 & 3 & 468.519 & $8.367 *$ \\
\hline & Within Groups & 14558.563 & 260 & 55.994 & \\
\hline & Total & 15964.121 & 263 & & \\
\hline \multirow[t]{3}{*}{ Annual Household Income } & Between Groups & 207.179 & 3 & 69.060 & 1.140 \\
\hline & Within Groups & 15756.942 & 260 & 60.604 & \\
\hline & Total & 15964.121 & 263 & & \\
\hline \multirow[t]{3}{*}{ Education } & Between Groups & 199.984 & 2 & 99.992 & 1.656 \\
\hline & Within Groups & 15764.138 & 261 & 60.399 & \\
\hline & Total & 15964.121 & 263 & & \\
\hline \multirow[t]{3}{*}{ Occupation } & Between Groups & 2308.725 & 4 & 577.181 & $10.947 *$ \\
\hline & Within Groups & 13655.396 & 259 & 52.724 & \\
\hline & Total & 15964.121 & 263 & & \\
\hline \multirow[t]{3}{*}{ Frequency of visiting the Bank } & Between Groups & 3077.057 & 3 & 1025.686 & $20.693^{*}$ \\
\hline & Within Groups & 12887.064 & 260 & 49.566 & \\
\hline & Total & 15964.121 & 263 & & \\
\hline \multirow{3}{*}{$\begin{array}{l}\text { Years of Relationship with the } \\
\text { Bank }\end{array}$} & Between Groups & 245.480 & 3 & 81.827 & 1.353 \\
\hline & Within Groups & 15718.641 & 260 & 60.456 & \\
\hline & Total & 15964.121 & 263 & & \\
\hline
\end{tabular}

$* 0.05$ level of significance 
Table 4 Mean and Standard Deviation of the Customer Satisfaction of SBI customers on basis of Age, Occupation and frequency of visiting the bank

\begin{tabular}{|c|c|c|}
\hline \multicolumn{2}{|l|}{ Age } & \multirow{2}{*}{$\begin{array}{c}\text { Total Customer Satisfaction } \\
40.50 \\
\end{array}$} \\
\hline \multirow{3}{*}{$<25$} & Mean & \\
\hline & $\mathrm{N}$ & 16 \\
\hline & Std. Deviation & 8.181 \\
\hline \multirow{3}{*}{$25-40$} & Mean & 39.17 \\
\hline & $\mathrm{N}$ & 202 \\
\hline & Std. Deviation & 7.970 \\
\hline \multirow{3}{*}{$>40$} & Mean & 44.70 \\
\hline & $\mathrm{N}$ & 46 \\
\hline & Std. & 4.821 \\
\hline \multicolumn{3}{|l|}{ Occupation } \\
\hline \multirow{3}{*}{ Salaried } & Mean & 39.41 \\
\hline & $\mathrm{N}$ & 162 \\
\hline & Std. & 7.235 \\
\hline \multirow{3}{*}{ Business } & Mean & 35.09 \\
\hline & $\mathrm{N}$ & 22 \\
\hline & Std. Deviation & 13.578 \\
\hline \multirow{3}{*}{ Retired } & Mean & 36.25 \\
\hline & $\mathrm{N}$ & 12 \\
\hline & Std. Deviation & 4.224 \\
\hline \multirow{3}{*}{ Student } & Mean & 45.58 \\
\hline & $\mathrm{N}$ & 48 \\
\hline & Std. & 4.748 \\
\hline \multirow{3}{*}{ Housewives } & Mean & 41.85 \\
\hline & $\mathrm{N}$ & 20 \\
\hline & Std. & 2.300 \\
\hline \multicolumn{3}{|c|}{ Frequency of visiting the bank } \\
\hline \multirow{3}{*}{ Weekly } & Mean & 48.17 \\
\hline & $\mathrm{N}$ & 24 \\
\hline & Std. Deviation & 6.391 \\
\hline \multirow{3}{*}{ 2-5/week } & Mean & 33.44 \\
\hline & $\mathrm{N}$ & 32 \\
\hline & Std. Deviation & 4.704 \\
\hline \multirow{3}{*}{ Fortnightly } & Mean & 39.09 \\
\hline & $\mathrm{N}$ & 44 \\
\hline & Std. & 6.675 \\
\hline \multirow{3}{*}{ Monthly } & Mean & 40.67 \\
\hline & $\mathrm{N}$ & 164 \\
\hline & Std. & 7.572 \\
\hline
\end{tabular}

\section{Conclusion}

When customer satisfaction was analyzed it was observed that there was a significant difference in the Customer satisfaction of SBI customers on the basis of gender, marital status, age, occupation and frequency of visiting the bank. The male customers of the SBI were more delighted and pleased with the bank as compared to the female customers. The married customers were more pleased and satisfied as compared to the unmarried customers. The students group was the most satisfied followed by the housewives and the salaried class. When the satisfaction levels were analyzed on the basis of frequency of visiting the bank it was found that the weekly visitors were the most satisfied as compared to the monthly and fortnightly visitors

Thus, this present research concluded that customer satisfaction is one of the most important factors in the public sector banks. The finding reinforces the need for banks managers to place an emphasis on satisfying the customers and take into account the moderating effect of demographics and situational factors. The managers should periodically assess and monitor customer satisfaction levels in their banks and recognize its importance in developing and maintaining enduring relationship with their customers as crucial parameters leading to increased performance. 


\section{References}

[1] Wang, C., Han, X., \& Wen, B. (2003). An empirical study of the relationship between customer's satisfaction and loyalty. Nankai Business Review, 4, 70-74

[2] Carter, T. (2010). The challenge of managers keeping customers. International Management Review, 6(2), $20-27$.

[3] Voss, G. B., \& Voss, Z. G. (2008). Competitive density and the customer acquisition-retention trade-off. Journal of Marketing, 72, 3-18.

[4] Chalmeta, R. (2006). Methodology for customer relationship management. The Journal of Systems and Software, 79, 1015-1024

[5] Peppers, D., \& Rogers, M. (2005). Customers don't grow on trees. Fast Company, 25-26.

[6] Kumar, V., \&Reinartz, W. J. (2006). Customer relationship management: A databased approach. Hoboken, NJ: Wiley.

[7] Leverin, A., \&Liljander, V. (2006). Does relationship marketing improve customer relationship satisfaction and loyalty? International Journal of Bank Marketing, 24(4), 232-251.

[8] Richards, K. A., \& Jones, E. (2008). Customer relationship management: Finding value drivers. Industrial Marketing Management, 37, 120-130.

[9] Jham, V., \& Khan, K. M. (2009). Customer satisfaction and its impact on performance in banks: A proposed model. South Asian Journal of Management, 16(2), 109-126.

[10] Wang, Y., H.P. Lo, R. Chi, Y. Yang, 2004. An Integrated Framework For Customer Value And Customer Relationship Management Performance: A Customer-Based Perspective from China, Managing Service Quality, 14(2/3): 50-60.

[11] Oliver RL, 1996, Satisfaction: A Behavioral Perspective on the Consumer, McGraw-Hill,New York

[12] Oliver,- R.L. (1997), "Service Quality And Satisfaction: A Behavioural Perspective On The Consumer, IrwinlMcgraw-Hill, New York, NY.

[13] Zeithaml, V.A. and Bitner, M.J. (2000), Services Marketing, McGraw-Hill, New York, NY.

[14] Baker, D. A. and Crompton, J. L. (2000) 'Quality, Satisfaction and Behavioral Intentions' , Annals of Tourism Research 27(3): 785804

[15] Vavra, T.G. (1997), Improving your measurement and customer satisfaction; a guide to creating, conducting, analysing and reporting customer satisfaction measurement programmes, ASQ Quality Press.

[16] Kotler, P. and Keller, K. L. (2009) Marketing management (13th end). New Jersey: Pearson Education Inc, Upper Saddle River

[17] Levy M.(2009) Customer experience management in retailing: An organizational framework

[18] Homburg, C. \& Giering, A. (2001) 'Personal Characteristics as Moderators of the Relationship Between Customer Satisfaction and Loyalty-An Empirical Analysis', Psychology \& Marketing, 18 (1), pp. 43-66

[19] Matzler, K., \& Sauerwein, E. (2002). The factor structure of customer satisfaction: An empirical test of the importance grid and the penalty-reward-contrast analysis. International Journal of Service Industry Management, 13(4), 314- 332.

[20] Zeithaml V. A., Bitner M. J., Gremler D. D. (2009) Services marketing, 5th edition, McGraw-Hill.

[21] Elanain, H. (2003) Staff Perceptions of Service Quality in Egyptian Commercial Banks: An Internal and External Perspective. Loughborough University.

[22] Foucault, B. \&Scheufele, D. (2002) 'Web vs campus store? Why students buy textbooks online', Journal of Consumer Marketing, 19 (5), pp. 409-423.

[23] Jabnoun, N. \&Khalifa, A. (2005) 'A Customized Measure of Service Quality in the UAE', Managing Service Quality, 15 (4), pp. 374-388.

[24] Bryant, B.E., and Cha, J., 1996 - Crossing the threshold, Marketing Research, Chicago, Winter, Vol. 8, Iss. 4, pg. 20, 9 pgs.

[25] Palvia, P. C., \&Palvia, S. C. (1999) - An examination of the IT satisfaction of small-business users. Information \& Management, 35(3), 127-137.

[26] Oyewole, P., 2001- Consumer's socio-demographic characteristics and satisfaction with services in the airline industry, services Marketing Quarterly, Binghamton, Vol.23, Iss. 2, pg.61

[27] Ogden, J. \& Ogden, D. (2005) Retailing: Integrated Retail Management. Boston: Houghton Mifflin Company.

[28] Kent, T. \& Omar, O. (2003) Retailing. New York: Palgrave Macmillan.

[29] Kotler, P. \& Armstrong, G. (2010)Principles of Marketing. 13th edn. London: Pearson.

[30] Kim, S. \& Jin, B. (2002) 'Validating the retail service quality scale for US and Korean customers of discount stores: an exploratory study', Journal of Services Marketing, 16 (3), pp. 223-237. 